\title{
Grundtvig i angelsaksisk kontekst
}

\section{Af Peter Balslev-Clausen}

Heritage and Prophecy. Grundtvig and the English-Speaking World. Edited by A.M. Allchin, D. Jasper, J.H. Schjфrring and K. Stevenson. Aarhus University Press, Århus 1993. 330 s. ISBN 877288447 9. Skrifter udgivet af Grundtvig-Selskabet, bind XXIV.

Udgiverne $\emptyset$ nsker med det foreliggende bind artikler om Grundtvig at præsentere ham som 'a great nineteenth century European' (Allchins formulering). Sproget er engelsk og projektet at gøre rede for Grundtvigs forhold til engelsk kultur og kirkeliv, hans indsats som digter, teolog, politiker, økonomisk og pædagogisk tænker, inspirator for folkehøjskolen og udviklingsarbejdet $\mathrm{i}$ den tredie verden.

Heritage and Prophecy går et skridt videre end Tradition and Renewal', der blev udgivet for at præsentere Grundtvig for den ikke-danske offentlighed $\mathrm{i}$ forbindelse med hans 200 årsdag 1983. Tradition and Renewal præsenterede den danske Grundtvig og den danske Grundtvig- forskning, hvor Heritage and Prophecy ønsker at se Grundtvig i forhold til England og engelsk kultur. Dette sigte giver bogen dens særpræg, er dens styrke og dens svaghed. Styrke, fordi Grundtvig herved bliver sat i forhold til den større verden, der omgav ham, og dermed taget ud af den provinsielle indsnævring, der har været kendetegnende for megen Grundtvig-forskning og Grundtvig-interesse i det hele taget. Svaghed, fordi Grundtvig herved bliver tvunget ind i relationer, hvor den naturlige sammenhæng mangler.

Udgangspunktet for Heritage and Prophecy er Grundtvigs livslange optagethed af engelske forhold med de fire englandsrejser som de naturlige højdepunkter. Efter A.M. Allchins indledende afsnit, 'Grundtvig and England. An Introduction' gennemgår Allchin og A. Pontoppidan Thyssen i 'Grundtvig's Relationship to England' Grundtvigs opfattelse af engelsk kultur og kirkeliv, først og fremmest den angelsaksiske arv og Oxfordbevægelsen. Derefter gør Bent Noack og S.A.J. Bradley rede for Grundtvigs beskæftigelse med og oversættelse af de gamle angelsaksiske manuskripter $i$ afsnittene 'Grundtvig and Anglo-Saxon Poetry' og '»The First New-European Literature«. N.F.S. Grundtvig's Reception of Anglo-Saxon Literature', hvorefter Jakob Balling i 'Grundtvig, Dante, Milton, and the Problem of European Continuity' stiller 'Nyaars-Morgen' sammen med 'Den guddommelige komedie' og 'Paradise Lost', der måske ikke har den store indbyrdes 
sammenhæng, men ikke desto mindre hver for sig betegner højdepunkter i europæisk kultur og litteratur.

Flemming Lundgreen-Nielsen giver i 'Grundtvig's Poetics' en oversigt over Grundtvig som digter, hans poetik og hans forhold til den litterære verden. I forlængelse heraf sammenstiller David Jasper i 'N.F.S. Grundtvig and S.T. Coleridge: The Hymnwriter and the Poet' de to digtere, efterfulgt af J.R. Watsons afsnit om 'Grundtvig and the English Hymn of the Romantic Period'. Hermed er skridtet taget til en redegørelse for Grundtvig som teolog. Det sker i Christian Thodbergs afsnit 'The Importance of baptism in Grundtvig's View of Christianity', hvor Grundvigs holdning til dåben indkredses gennem en analyse af centrale prædikener og salmer. Grundtvigs salmedigtning tages derefter op i Kenneth W. Stevensons karakteristik af 'Grundtvig's Hymns from an Anglical Point of View'. Derefter giver Theodor Jørgensen ud fra 'Kirkens Gienmæle' en karakteristik af Grundtvig som teolog, der sker i afsnittet 'Grundtvig's The Church's Retort - in a Modern Perspective', samtidig med at Geoffrey Wainwright i 'Reason and Religion' giver en analyse af 'A Wesleyan Analogue to Grundtvig on Modernity and the Christian Tradition, et modstykke til Jens Holger Schjørrings redegørelse for 'Church Continuity and the Challenge of Modernity: Grundtvig, the Oxford Movement and Rationalist Theology'.

Lorenz Rerup skriver om 'N.F.S. Grundtvig's Position in Danish Nationalism' og Vagn Wåhlin om 'Denmark, Slesvig-Holstein and Grundtvig in the $19^{\text {th }}$ Century, hvorefter afsnittet om Grundtvig som pædagogisk tænker følger med K.E. Bugges 'The School for Life: The Basic Ideas of Grundtvig's Educational Thinking', der kort og klart gør rede for Grundtvigs pædagogiske tanker før Hans Henningsens afsnit om 'The Danish Folk High School'. Bindet slutter med Holger Bernt Hansens afsnit om 'Grundtvig and the Third World: The Transfer of Grundtvigs's Ideas to Other Peoples and Cultures'. Afsnittene er skrevet af forskere, der hver på deres felt repræsenterer henholdsvis den danske og den engelske ekspertise på området. Bogen er derfor spændende og fængslende læsning. Både englændere og danskere vil have udbytte af at læse bogen, der ligeså meget er en introduktion for danskere til engelsk kirke-, litteratur- og kulturhistorie, som den giver en solid indføring Grundtvigs liv og forfatterskab til sin engelske læsere.

Som noget nyt er en række af Heritage and Prophecy's artikler skrevet af englændere. For en dansk læser er det deres bidrag, det er mest spændende at læse, da det er dem, der nødvendigvis skal bære bevisbyrden med hensyn til, hvorvidt Grundtvig var 'a great nineteenth century European'. Flere af de engelske forfattere kæmper tydeligt med den vanskelighed det er ikke at kunne læse Grundtvig på dansk og derfor at være henvist til de ret få og tilfældige Grundtvig-tekster, der er oversat til engelsk. Nogle klarer sig 
ved at sammenligne Grundtvig med en eller flere englændere, idet de bruger størstedelen af deres artikler til at omtale de englændere, de sammenligner Grundtvig med. Det gælder ikke mindst David Jasper, der sammenligner Grundtvig og Coleridge, og Geoffrey Wainwright, der sammenligner Grundtvig og Charles Wesley, ligesom J.R. Watson gør langt mere ud at de engelske salmedigtere fra den romantiske periode, end han $\mathrm{g} \varnothing \mathrm{r}$ ud af Grundtvig og hans oversættelser af samtidens engelske salmedigtere. J.R. Watson har yderligere det handikap, at hans kendskab til Grundtvigs salmedigtning stammer fra læsning af især nordamerikanske brugsoversættelser af en række Grundtvig-salmer, oversættelser, der for manges vedkommende langtfra yder Grundtvigs originaler retfærdighed. Helt anderledes forholder det sig med Kenneth Stevensons anglikanske vurdering af Grundtvigs salmer. Kenneth Stevenson kender Grundtvigs salmer så godt som nogen dansker. Til gengæld bekræfter hans artikel, at afstanden mellem en grundtvigsk og en anglikansk kirke- og gudstjenesteforståelse er om ikke uovervindelig, så dog langt større, end de fleste formodentlig regner med. Tættest på en genuin Grundtvig-forståelse kommer A.M. Allchins introduktion til bogens $\varnothing$ vrige bidrag. lkke alene overbeviser Allchins præsentation af Grundtvig læseren om, at Grundtvig virkelig var en stor europæer, den vil også fremover hmne bruges som en almen indføring for engelsksprogede læsere til Grundtvig og hans forfatterskab. Uden problemer er også S.A.J. Bradleys gennemgang og analyse af Grundtvigs forhold til den angelsaksiske litteratur. Her skriver en engelsk forsker om sin fagfælle fra 19. århundrede og gør det med forståelse og respektfuld kritik, på samme måde som Bent Noack skriver om Grundtvig og den angelsaksiske digtning, to fremragende artikler. Jakob Balling og Flemming Lundgreen-Nielsen skriver hver på deres måde om Grundtvig som digter, Balling i europæisk perspektiv, Lundgreen-Nielsen i forhold til Grundtvig selv og hans egen danske samtid, også hver på deres måde to fremragende artikler. Christian Thodberg giver i sin artikel et klart og instruktivt tværsnit af Grundtvig som teolog, prædikant og liturgisk nyskaber gennem sine salmer. Det er et voveligt og spændende projekt at lade en systematiker som Theodor Jørgensen skrive om Grundtvigs opgør med al systematisk teologi i Kirkens Gienmale, men Theodor Jørgensen har i sin artikeI løst opgaven overbevisende, ikke mindst ved at karakterisere Grundtvigs kirkesyn som antihierarkisk og hans teologiske koncept som historisk og ikke systematisk. Jens Holger Schjørring beskæftiger sig med den samme problematik i sin artikel, hvor han viser, at Grundtvig stod lige langt fra tyskeren D.F. Strauss og de engelske højkirketeologer i Oxford-bevægelsen. SchJørring finder, at studiet af Grundtvig ikke skal føre til en gentagelse af hans synspunkter, men til et videre arbejde med de samme problemer, inspireret af Grundtvigs løsningsfors $\emptyset$ g. 
Lorenz Rerup og Vagn Wåhlin har begge i deres artikler om Grundtvigs forhold til henholdsvis det nationale spørgsmål og datidens nationaløkonomiske sammenhæng svært ved at få placeret ham i disse sammenhænge, modsat K.E. Bugge og Hans Henningsen, der begge med stor præcision og klar fremstillingsevne gør rede for Grundtvigs pædagogiske helhedssyn og dets virkningshistorie, d.v.s. dets evne til i 150 år at inspirere højskolebevægelsen og holde den fast på dens opgave.

I sin afsluttende atikel gennemgår Holger Bernt Hansen de forskellige fors $\varnothing \mathrm{g}$ på at omplante ikke mindst folkehøjskoletanken til en tredieverdens-sammenhæng, både hvor der har været tale om danske forsøg på at eksportere højskoletanken, og hvor der har været tale om at ikke mindst skolefolk fra den tredie verden har ladet sig inspirere af Grundtvigs skoletanker. Holger Bernt Hansen konkluderer på samme måde som Jens Holger Schjørring, at inspirationen fra Grundtvig ikke skal føre til gentagelse, men til videreførelse af Grundtvigs analyser og handlingsforslag.

For den, der i forvejen kender mere eller mindre til Grundtvigs forfatterskab og tankeverden, åbner Heritage and Prophecy spændende nye perspektiver ved tydeligere end det er sket tidligere at se Grundtvig udefra. Heritage and Prophecy's Grundtvig er stadig den gammelkendte Grundtvig, men nok mere levende og spændende og favnende, end han som regel er blevet fremstillet. Bogens mange bidrag vil kunne læses med lige stort udbytte af både englændere, andre udlændinge, og danskere. Bogen bør inspirere til et fortsat dansk-engelsk samarbejde indenfor Grundtvigforskningen. Samtidig bør Heritage and Prophecy følges op af et systematisk arbejde med at oversætte Grundtvig-tekster til engelsk. Når Grundtvig er temmelig ukendt i det store engelsktalende udland, skyldes det først og fremmest, at der kun foreligger ret få brugbare oversættelser til engelsk af hans centrale skrifter. Der ligger her en stor opgave og venter ikke blot på kredsen af forfattere bag Heritage and Prophecy, men også på de to institutioner bag udgivelsen, Center for Grundtvig Studier ved Aarhus Universitet og Grundtvigselskabet. Der er ingen tvivl om, at et sådant oversættelsesarbejde i sig selv vil inspirere til et fortsat dansk-engelsk forskningssamarbejde om Grundtvig. Heritage and Prophecy er et godt varsel om, hvad et sådant samarbejde vil kunne føre med sig. 